\title{
Between Certainty and Contingency: On the Way to a New Understanding of Islamic Theology and Religious Education in the European Context
}

\section{Introduction}

To choose 'Between Certainty and Contingency' as the title for an inaugural address may appear to be unusual and unexpected, given all the attempts - especially in the discussion of religious themes - at clarity, certainty, and truth. If we look at the situation in which we find ourselves, the necessity of the problematisation of clarity, certainty, and truth quickly becomes evident. Against the background of many discussions that are conducted in the context of religion, especially that of Islam, from the internal and external perspective, a tension between certainty and contingency becomes visible when we look more closely. This tension can be understood as possibility, in one way or another and thus as constantly different.

This essay is a response to that problem. It is divided into different consecutive and interwoven sections. The introduction is followed by a description of the state of affairs at this time, and the consequences of that state of affairs are outlined in the subsequent section. These consequences will then be made fruitful in approaches for a new understanding of Islamic theology and religious education in the European context. In connection with this, I will present my view of anthropology, revelation, and the significance of the context as basic components of a newly interpreted Islamic theology and religious education in the European context. This in turn permits the formulation of principles for Islamic education in the European context. The final section is concerned with the significance of these foundations for an academic encounter in Islamic theology and religious education at present.

In line with my academic-methodological approach, this essay first presents an overview of the current discourse regarding Islam.

Note: This essay is an edited version of my inaugural lecture on 13/01/2016 at the University of Innsbruck.

Ә OpenAccess. ( 2022 Zekirija Sejdini, published by De Gruyter. (cc) BY-NC-ND This work is licensed under the Creative Commons Attribution-NonCommercial-NoDerivatives 4.0 International License. 


\section{Description of the State of Affairs}

There is hardly any theme that is discussed so broadly, so intensively, so controversially, and emotionally at present as Islam; there is hardly any social area that is not permeated by the discussion on this topic. In other words, everybody is talking about Islam today. It is striking that, since the terrorist attacks on 9/11 in New York, the discourse on Islam has generally - if not exclusively - been negatively charged and far removed from the objectivity that is completely usual in other areas. This has resulted in Islam being discussed in an unreflective and undifferentiated way, especially in the media. But this has complicated possible solutions and causes rifts in our multicultural and multireligious society. An urgently necessary constructive analysis of this theme thus appears further away than ever.

If we look at the current discussion on Islam, a plurality of themes comes into view that are addressed in this context: at one point it concerns political Islam, at another the compatibility of Islam with democracy and constitutional secularity, and at yet another freedom of opinion and of religion, then women's rights, Islam's view of homosexuality, and last but not least Islam's potential for violence - and the list goes on. Given the often monocausal explanations of the problems mentioned, it is not surprising that objectivity and a concomitant analysis based on multicausal explanations fail to appear and that religion in general and Islam in particular are presented as a problem and danger for society.

This discourse on Islam is dominated at the present time by - generally speaking - two entrenched positions that make an objective analysis impossible. The first position is the main one taken by Muslims and can be characterised as an 'apologetic' approach or one in which Muslims take on the role of 'victim'. It disputes any need for reform on Islam's part and always seeks the reasons for Muslims' problems elsewhere. For this group, the advice to engage in 'self-criticism' is undesired and insulting. Critique from outside is viewed either as proof of Islamophobia by non-Muslims or, when made by Muslims, as heresy. Regarding the latter, proponents of this position have often developed conspiracy theories and see the critics as the henchmen of dark powers who want to use reforms to distort Islam into something unrecognisable. The solution is found in a backwards-looking 'back to their roots' movement in a blind imitation of the prophetic age, which promises unambiguous orientations and clear truths (Behnam \& Fouad, 2014).

The second position, which dominates the discourse on Islam and is diametrically opposed to the first, is mainly represented by non-Muslims and suggests that there is an essential interrelation between Islam and violence, politics, and intolerance (Raddaz, 2005; Rhonheimer, 2012, 329). Thus, the proponents of this 
position hold that Islam lacks compatibility with Western values in principle because of this interrelatedness. That is why neither consideration of human rights nor the recognition of a democratic secular society can ever be expected from Islam because they are foreign to the essence of Islam. Any attempt at a harmonisation of democratic values with Islam is, for the advocates of this position, a deviation from 'true Islam' (i.e., their understanding of true Islam) and contradicts an allegedly 'original Islam'. That is why, for the proponents of this view, those who assume several different versions of Islam are either blue-eyed nonMuslims who do not see the truth, Muslims who disguise themselves so they can infiltrate Europe and islamicise it, or Muslim heretics who have become so secularised that they no longer speak on behalf of Islam.

If we compare the beliefs of both groups, we can discover similar mindsets behind the two positions. Both assume the existence and unequivocalness of one (their own) understanding of Islam and ignore the perspectivity of their own perceptions, statements and convictions. They thus persist in the static, unchangeable truths that they see as valid for all time and which they consider themselves to be in possession of, denying directly or indirectly the presence of the other and withdrawing from the encounter with plurality. It is a mindset that has caused a great deal of suffering in human history in its various stages of development.

It is precisely this mindset that is the concern of this essay, by placing the awareness of contingency over against certainty and thematising the tension. Contingency is understood here in the sense of possibilities/awareness of possibility - entirely in the spirit of the philosophical, theological, and literary positions, it is contingency in the sense that it is also possible to conceive of something else than what actually is. According to this understanding, contingency leads to plurality, and plurality in turn draws ambivalence and ambiguity to itself (KramI, 2019, 330 -348).

The German mathematician and physicist Max Born was probably aware of something similar. I quote him here:

I believe that ideas like absolute correctness, absolute precision, definitive truth, etc. are fantasies that should not be admitted to any science.... This easing of our thinking seems to me to be the greatest blessing that contemporary science has brought us. But belief in a single truth and to be its possessor is the deepest root of all evil in the world. (Born, 1965, 183)

Based on these considerations, the fundamental attitudes to the academic analysis of theological and religious educational themes can be traced. With that in mind, I see myself challenged as a Muslim religious educationist to question my 
own traditional foundations of theological and religious educational thinking in light of the tension between certainty and contingency.

This essay should also be understood as committed to this principle. Instead of ignoring the endeavours, tendencies, and ambivalences, Islamic religious pedagogy should be seen as an independent kind of theologising that, precisely because of those tensions, has constructive and active potential. In doing so, it sounds out the feasible ways of providing European Muslims with an approach to their religion that corresponds to the European context. It seems to be extremely important in these difficult times to be able to offer, through embedding the discipline in a university, religious educational viewpoints that are characterised by multi-perspectivalism, academic reflection, and interdisciplinary models (Sejdini, 2015b).

Such approaches promote an understanding of theology that is compatible with religious education and show a high degree of contingency sensitivity in the sense of an awareness of possibilities. The title of this essay, 'Between Certainty and Contingency', speaks of a new understanding of theology and religious education. The question arises as to what innovation consists in and whether the innovation being sought can be developed out of the Islamic perspective. Any attempt to renew an Islamic theology and religious education from outside and any introduction of foreign elements would only create resistance and isolation and would thus be condemned to failure.

\section{A Contingency-Sensitive Theology and Religious Education}

A theology that is compatible with religious education cannot be understood as a completed, static entity that believes itself to be in possession of the absolute truth or aspires to convey this. As Norbert Mette and Friedrich Schweitzer correctly argue, a theology that is

to be understood as grounded in eternal and unshakeable truths, thus as speculation removed from temporal and contextual contingencies, and that claims its insights have universal validity can only lead to indoctrination and to the immaturity of its indoctrinated persons. (Mette \& Schweitzer, 2002, 37)

Such a theology cannot be used for carrying out the task of education. Unfortunately, this - with a few exceptions - applies to a number of current theological approaches.

We will thus attempt to present theology here not as an isolated activity carried out by eccentric scholars in an ivory tower. Rather, it should be made clear 
in our discussion how theology - in this case Islamic theology and religious education - develops on the one hand out of a specific social and cultural reality as well as, on the other, how it affects that society in turn by fulfilling the elementary function of explaining the world and the attribution of meaning for that society.

But how do we arrive a possibility-sensitive understanding in Islamic theology and religious education? What line of argument can we follow about this? To what extent can this line be compatible with the sources of Islam, and how can a theological narrowing be avoided? To be able to develop - as indicated in the above questions - authentic theological and religious educational approaches from the Islamic sources, we will explore three main pillars below that constitute basic conditions for every Islamic theology and religious education that connects with the world it lives in. If one looks at the usual Islamic theological and religious educational discussions, they reveal the greatest obstacles to such an understanding precisely in the basic pillars addressed. These pillars (anthropology, revelation, importance of the context) are programmatic for my own understanding of theology and religious education because they are the measuring stick for a quality theology and religious education.

\subsection{Anthropology as a Starting Point}

All theological and religious educational considerations are based on specific concepts of humanity that are usually derived from their respective holy texts. Even though these fundamental anthropological assumptions are not always the subject of reflection, they are always present. Thus, the theological and religious educational approaches provide information on the concepts of humanity that lie at their foundation. It is therefore not difficult to explore the concept of humanity that grounds a theology that forbids women from driving cars with theological arguments - thus in the name of God - as was the case until recently in Saudi Arabia.

From this perspective, it is the task of academic theology and religious education to research and explain the usually implicit concepts of humanity. This kind of explication and 'deconstruction' is a necessary measure for gaining distance to reflect and to create new approaches.

Theology and religious education are human products that - based on their relation to context and the subject - have subjective and contingent characteristics. That means that, in an anthropological analysis, pluralist concepts of humanity become visible even though the religious sources are the same. Nevertheless, the plurality of anthropological assumptions is not only due to the 
perspectivity of human beings; it is also caused by the religious sources, which contain various, ambivalent, and even partly apparently contradictory expressions. Especially in Islam, the plurality of the interpretations of sources is advanced by the lack of an institutionalised authority.

The lack of a supreme theological authority in Islam that has the prerogative over interpretations of the source can appear to be a weakness in the contemporary context. Nonetheless, given the prevalent theological positions in Muslimmajority countries, God cannot be thanked enough for the lack of an Islamic 'church'. I say this not only because many colleagues who do research at European universities would not receive any nihil obstat, but no institutional decision is required to derive concepts of humanity from the sources that correspond to the present context, reinforce the humanistic concept of humanity, and make new theological approaches in the European context possible.

We now come to the content of new anthropological approaches, which are both sensitive to context and contingency and are authentically compatible with the Muslim tradition. Here, three characteristics can be found both in the Islamic sources and in the understanding of Muslim scholars. These characteristics are human dignity, reason, and freedom from which human responsibility is also derived.

\subsubsection{Human Dignity}

The Islamic sources contain many direct and indirect references to human dignity. The most important direct reference to the God-given inviolable dignity of the human person is provided in the verse in which God says that He has bestowed dignity on all people, not only Muslims (Q 17:70). Though the Qur'an does not explicitly state what that dignity consists in, it is nevertheless the most important foundation for an inclusivist understanding on which human rights can be based. Unfortunately, this approach, which places human dignity at the centre, has often not been continued - as it was in many other theologies - in classic Islamic theology. Only in Islamic mysticism can some traces of this be found (Schimmel, 1995).

In addition to the direct references found in the Qur'an, above all in the Qur'anic creation narrative, there are several indirect references that point to human dignity. Examples of these are the creation of human beings in the best possible form ( $Q$ 32:7), the in-breathing of the divine spirit ( $Q$ 32:9), as well as the appointment of the human being as God's viceregent on earth (Q 2:30) These are only some of the Qur'anic verses that point to the special status of all human beings, from which the dignity of all people can be derived (Renz, 2002). 
The embedding of God-given and inviolable human dignity in theological and religious educational considerations is an indispensable condition for the development of a contingency- and context-sensitive theology and religious education. In the current context, this means that a theology that does not take human rights, in which the special dignity of all people has found expression at present, into consideration is inconceivable.

\title{
3.1.2 Reason
}

Another crucial anthropological feature is human reason. God has equipped human beings with reason and selected them to be God's communication partners. Because of reason, the human being is able to be addressed by the divine message and to respond to it. At the same time, however, he/she is also challenged to explore his/her environment, to enter into communication with others and to acquire new knowledge, which can in turn be put into service for humanity. That is why the Qur'an time and again challenges human beings to use their reason to continue to develop society (Q 6:32). Although the gift of reason is an essential property of the human being and the condition for communication with God, it has often been neglected in Islamic theology and religious education. Consequently, however reason, which is a gift of God and is constitutive for faith, is viewed as an obstacle and often combatted.

\subsubsection{Freedom}

Closely related to reason is human freedom, and here we arrive at the third anthropological property. Human freedom is also an essential characteristic, one that distinguishes humans from other creatures. It is fundamentally ambivalent: it can lead to good things or to disaster. Although human freedom as a possible source of misery was already announced by the angels, God himself wished to take that 'risk' to create a living being that, given these characteristics of dignity, reason, and freedom, is able to go his own way and to decide for or against God. This is portrayed in the Qur'an as follows:

\begin{abstract}
AND LO! Thy Sustainer said unto the angels: 'Behold, I am about to establish upon earth one who shall inherit it.' They said: 'Wilt Thou place on it such as will spread corruption thereon and shed blood - whereas it is we who extol Thy limitless glory, and praise Thee, and hallow Thy name?' (God) answered: 'Verily, I know that which you do not know.' (Q 2:30)
\end{abstract}

These three anthropological aspects - dignity, reason, freedom - should not be viewed as isolated, for they are bound up with the responsibility that God be- 
stowed on the human being for himself and for his world, and they show that the human being is responsible for his/her own actions.

Accordingly, what is needed is - as Karl Rahner formulated it - an 'anthropological turn' in Islamic theology and religious education that takes into account human beings in their responsibility and places them at the centre of Islam's theological and religious pedagogical reflections. Kenneth Cragg also advocates this approach when he says: "As reverent theists we can be sure that we shall never be far away from a living theology if we are radically and honestly committed to understanding man" (Cragg, 1977, 3). With these remarks on anthropology, we now come to two fundamental components.

\subsection{Revelation of the Transference of Knowledge for Communication}

Despite the anthropological notion of a free human being gifted with reason, Islam - like, incidentally, all monotheistic religions - sees divine revelation as the condition for responsible human action. Here, the question arises as to how revelation must be offered in a way that it can correspond to the anthropological properties indicated above. A revelation oriented to dignity, reason, and freedom can only be understood as a kind of communication that is directed at giving orientation to human beings through "right guidance" (Thurner, 2011).

This implies that revelation should not be understood as tutelage for humans in the form of an instruction, as the 'objective' conveying of knowledge. Nor should it be understood as something that is solely justified by an authority that stands above human reason. Rather, it should be viewed as a process of communication that involves subjectivity and is kept vital precisely through reason and freedom, constantly being interpreted anew and being made fruitful.

The primary source of revelation in Islam, the Qur'an, must also be understood in this context. Even though the Qur'an is seen as being inspired word for word, this does not present any obstacle to understanding it as a contextual process of communication (Abu-Zaid, 2008). For, as Harun Behr correctly states, “it changes one's thinking and deepens faith if history is understood not as the predicate of the Qur'an but the Qur'an as the product of history” (Behr 2014, 59).

Nevertheless, Islamic theology has, generally speaking, kept to the idea of the Qur'anic revelation as the transmission of information and instruction. Especially in fundamentalist circles, this becomes evident in an all too normative, literal, and contextless reading with an all-encompassing claim. This claim results in the human being not being taken seriously, being left to stagnate and no longer able to develop any further. In addition, truth as a whole is reduced to one revealed book. Thus, through false ascriptions, revelation, which should actually 
open up ways for the development of humankind, instead becomes an obstacle to that development.

The Qur'an itself challenges human beings to use their reason and not to close themselves off from signs of God outside the Qur'an. The Qur'an says:

\begin{abstract}
Verily, in the creation of the heavens and of the earth, and the succession of night and day: and in the ships that speed through the sea with what is useful to man: and in the waters which God sends down from the sky, giving life thereby to the earth after it had been lifeless, and causing all manner of living creatures to multiply thereon: and in the change of the winds, and the clouds that run their appointed courses between sky and earth: (in all this) there are messages indeed for people who use their reason. (Q 2:164)
\end{abstract}

As Thomas Bauer says, this concerns a theology and religious education that is open to plurality and is tolerant of ambiguity (Bauer, 2011). It embraces new approaches to revelation in the sense of the anthropological characteristics of dignity, reason, and freedom.

\title{
3.3 Contextuality
}

Contextuality is the last of the basic pillars to which I will refer in this connection that plays a constitutive role in the development of new theological approaches. It is contextuality that brings contingency, plurality, ambivalence, and ambiguity to the fore and makes clear the mediated nature of our approaches. It thus appears, according to Joachim Willems,

\begin{abstract}
necessary to reject the idea of an unmediated depiction of the world. The image of the world that we form, thus of our natural environment and our fellow humans as well as of the values that in our view have greater or lesser validity, depends essentially on our cultural and religious context. It is not only the interpretation of experiences and perceptions that is culturally and religiously determined. Rather, there are no 'pure' experiences and perceptions that are not influenced by culture and religion. How something and the fact that something is perceived at all or experienced (and what not) occurs within a cultural-religious frame and is already the result of previous perceptions and experiences that are again constructed in a specific (culturally and religiously contingent) way. (Willems, 2011, 65)
\end{abstract}

This way of thinking makes clear that it is not possible to understand anything without including the context.

Traditionally, Islamic theology was often connected to the corresponding contexts and could stimulate those same contexts in turn. This was also the reason why the Islamic world became the centre of the civilised world between the 
eighth and the twelfth centuries and enriched the world with respect to art, philosophy, and in other scientific and academic ways.

Only in the wake of an encounter with secular society, which went very badly in many regions because of colonisation, was the secular interpretation of Islam understood as a defeat and capitulation and consequently as humiliation. This led to resistance to contextualisation, as if the responsibility lay with the times and not in the inability to adapt to circumstances. This aversion to contextuality is still present in many parts of Islamic theology and religious education. Especially in a secular environment, which is strange to their tradition, Muslims see contextuality as a watering down of Islamic theology and take an apologetic attitude (Bielefeldt, 2003a). Europe is characterised by the democratic secular constitutional state. Thus, Islamic theology and religious education should include democracy and secularity as constitutive components to ensure their place in a multicultural and multireligious society.

\section{Principles for Islamic Religious Education in the European Context}

Starting from the basic pillars discussed above, which represent my view of theological and religious education, the justified question arises as to the possible effects of the proposed transformations in anthropology, the understanding of revelation, and contextuality for Islamic theology and religious education. This concerns the development of an Islamic religious education as a theory of religious education that meets academic and scientific standards and the European context. According to the German educationist and theologian Helmut Peukert,

the interpretation of a living religious tradition will not only reconstruct its genesis and historical understanding. It is also directed, in its practical interpretation, at its 'application' in a contemporary situation. For the next generation is always confronted with the question whether this tradition itself opens or closes opportunities for life in the future. (Peukert, 2004a, 83)

An Islamic religious pedagogy conceived in this way should be oriented to the following principles:

- All people are equal in dignity: No one should be placed at a disadvantage or advantage because of his or her allegiance to a religion or non-religion. With reference to religious education, students should not be taught that their own religious group is superior to others because of religious adherence.

- Faith is an offer by God: As such, faith can be accepted or rejected based on one's God-given freedom. In term of religious pedagogy, this ability to decide 
must be given to every person, without that person having to fear that he or she will lose any rights or respect as a person.

- Coercion destroys faith: A reflective religious education takes into account the unavailability of faith. To coerce faith is neither permitted nor desired nor in accordance with the Creator. Freedom is the condition for true religiosity. Only where freedom exists, to be for or against God, can one presuppose authentic religiosity. This is also clarified in the Qur'an, where we read: "The truth (has now come) from your Sustainer: let, then, him who wills, believe in it, and let him who wills, reject it” (Q 18:29).

- Faith is a personal experience: If we assume this, Islamic religious education needs to display an attitude of recognition and respect towards other religions and worldviews. This approach constitutes the key to a respectful attitude towards the other in a multicultural and multireligious democratic society.

- Faith does not exclude reason and science: A properly scientific and academic religious education must keep one thing in mind: faith should not be built on the disregard of reason nor the banishment of science. The task of revelation consists in stimulating people into encounters with science and not the promotion of one's own kind of scientific knowledge. It is often overlooked

that it must often come down to a productive tension between religious institutions and their own traditions of knowledge management on the one hand and the culture of academic disciplines on the other. Islamic theology can do justice to its cultural and political task only if it enters into the religious discourse. (Behr, 2014, 58)

- Not everything can be found in the texts of revelation: Scientific and academic conclusions must neither be confirmed nor derived from these texts. The attempt to verify scientific conclusions theologically would be both a theological narrowing as well as a distortion to some extent of the fundamental intention of revelation and can lead to indoctrination and thus to immaturity (Özsoy, 2006a).

- Maturity in the sense of taking one's own initiative as the principle of religious education: Because of the desire to convey content, the danger of keeping the other in a state of tutelage and deciding for another is great. An Islamic religious pedagogy in our sense is not to be understood as teaching specific truths but as guiding those searching for truth.

- Secularity and democracy as constitutive ideas of religious education: Secularity guarantees the freedom of religion and enables the unfolding of various worldviews and religions. This alone makes religious plurality possible and entails a major challenge for religious education to cultivate religious plural- 
ity, to promote it, and to see it as an enrichment. This entails the "willingness to change and to adapt" (Krainz, 2014, 61) and less "the perpetuation of habits, customs, and traditions" (ibid.). Such a religious education is inherent to a democratic ethos. This should "not only enable and allow but challenge one to engage in and promote social change. It concerns the training of a habit [of mind] that continually encounters itself as well as the world and others" (ibid.) which, in principle, means nothing other than appropriating an educational habit or a habit of education.

- The university encounter with Islam: Islamic self-interpretation must be transformed if it is to meet the conditions of the secular university. Here it is not a question of the "perpetuation of previous Islamic knowledge", according to the German expert on Islam Reinhard Schulze, "but the secular university determines an order of 'Islamic' knowledge that corresponds to the character of a secular university" (Schulze, 2012, 183). The condition is that both orders, 'religion and society' are viewed as mutually respectful orders (ibid.).

\section{Truth, Certainty, Contingency}

In the light of what I have written up till now, it is clear that the question of truth and certainty is in one way or another the core concern of all the abovementioned discussions. Therefore, Islamic theology and religious pedagogy at present, like every other theology and religious pedagogy, is concerned with, among other things, sounding out a context-sensitive approach to the problem of truth and certainty.

The religious educational task consists in reinforcing contingency-sensitivity. It is not to qualify the awareness of one's own limitations as a sign of deficiency but to use those limitations in a productive way. Precisely in this connection, it must be made clear that it cannot be a matter of eradicating contingency but one of facing it and dealing with it. From the point of view of religious pedagogy, "a deeper faith [shows itself] ... not in the absence of doubt but in the constant processing of it". "Islamic theology should consequently cultivate more the attitude of questioning. Its task lies less in providing answers than making answers possible" (Behr, 2014, 59). It is, after all, not answers that open up the world; questions do. As Lotte Ingrisch writes, "we flourish not from answer to answer but from question to question" (quoted in Brunner et al., 2015, 129). Such an attitude would restore to religion, in this case Islam, its lost ability at present to speak to all of humanity and to enable it to develop theological and religious educational conceptions that speak, as one of my colleagues said, to 'both Hassan and Hans'. 
Even if this contingency-sensitive attitude appears at first glance to be unacceptable, especially in religion, it represents a maxim for every theological and religious-pedagogical consideration that sees its primary task in understanding religion as a special way of being human. Viewed in this way, Islam will also be understood as one of the most superb possibilities and ways of "being human" (Smith, 1981, 12).

That this development of a contingency-sensitivity is possible despite all difficulties is shown in an impressive way by the ideas of a shaman. I will close this essay with quoting him:

Question: 'Why should someone follow a spiritual path if all one desires at the end is the knowledge that one does not know?' Shaman: 'There is a beauty in this kind of not-knowing. It is a not-knowing and not a cluelessness. And with time, you desire to reach a point in which you embrace the idea that you know nothing. You have thus come so far that this not knowing actually becomes enjoyable because it lets you remain open to constantly expand your perception. It is like a dance, remaining stable and open at the same time. It is truly an interesting dance because it is a skill. Everyone can learn a skill, but this kind of skill is very difficult to learn because it is so contrary to our usual way of thinking. You must know that at bottom you know nothing and must be content with that. In this way, you will always be open to the mystery. In my view, this is what every good spiritual path should teach. (Kalisch, 2010, 51) 
